Vol. 2 | No. 2 | 2021 | Hal. 118-123

\title{
PEMBUATAN ECO-ENZYME SEBAGAI SOLUSI PENGOLAHAN LIMBAH RUMAH TANGGA
}

\author{
Mohammad Rifqi Junaidi*, Muhammad Zaini, Ramadhan, Muhammad Hasan, Bryen \\ Yuzac Zein Baneka Ranti, Muhammad Wahyu Firmansyah, Silvia Umayasari, Anggi \\ Sulistyo, Rochmathul Duwi Aprilia, Fahrudin Hardiansyah \\ Fakultas Agama Islam, Universitas Islam Malang \\ *korespondensi email: rifqijunaedi@unisma.ac.id
}

\begin{abstract}
ABSTRAK
Tujuan yang ingin dicapai dalam melaksanakan kegiatan pengelolaan sampah dengan membuat eco-enzyme adalah untuk membantu memudahkan masyarakat dalam mengolah limbah rumah tangga di Dusun Kandangan, Desa Gunungsari, Kecamatan Bumiaji, Kota Batu. Pada masa pandemi ini, kegiatan pengelolaan sampah ini bisa menjadi solusi dalam menghemat pengeluaran rumah tangga. Hal ini dikarenakan hasil fermentasi dari ecoenzyme mempunyai banyak manfaat seperti pembersih lantai alami, pembersih kloset, bisa melancarkan saluran air yang tersumbat. Selain itu, bisa juga digunakan untuk menyiram tanaman akan memberi hasil buah, bunga, atau panen yang lebih dan dapat mengusir serangga-serangga pengganggu. Ampas sampah organik yang sudah difermentasi bisa digunakan sebagai bahan untuk kebersihan dan juga sebagai pupuk organikyang baik. Modal untuk membuatnya juga murah dan praktis.
\end{abstract}

Kata Kunci: eco-enzyme; limbah rumah tangga; pandemi covid-19

\section{PENDAHULUAN}

Pemeliharaan lingkungan hidup merupakan kewajiban bagi semua umat manusia. Pada sektor sumber daya alam dan lingkungan hidup perlu memperhatikan upaya melestarikan dan penggunaan secara bijaksana agar anak cucu kelak juga bisa ikut merasakannya (Gischa, 2021). Pengelolaan lingkungan termasuk pencegahan, penanggulangan kerusakan dan pencemaran serta memulihkan kualitas sumber daya yang telah di eksploitasi secara habis-habisan (Listiyani, 2017).

Pengelolaan Lingkungan Hidup adalah upaya melestarikan fungsi lingkungan hidup yang meliputi berbagai kebijakan didalamnya seperti penataan lingkungan, pemanfaatan sumber daya alam, pengembangan sumber daya, pemeliharaan sumber daya dan lingkungan sekitarnya, pemulihan keanekaragaman hayati dan hewani, dan pengendalian lingkungan hidup. Semua ini berkaitan dengan makhluk hidup di sekitar sumber daya termasuk manusia dan juga semua jenis perilakunya yang mempunyai dampak terhadap lingkungan (Clourisa et al., 2021; Endah, 2015).

Berkaitan dengan aktivitas manusia berarti tidak akan terlepas dari sampah atau limbah. Menurut Yusuf (2008), sebagaimana dikutip oleh Suswanto, dkk. menyatakan bahwa semakin tinggi aktivitas manusia, maka akan semakin tinggi pula sampah atau limbah yang dihasilkan dari waktu ke waktu. Sampah adalah sisa kegiatan sehari-hari manusia atau 
proses alam yang berbentuk padat atau semi padat dan berupa zat organik atau anorganik yang sudah lagi dibutuhkan oleh manusia (Megah et al., 2018).

Pada hakikatnya sampah bukanlah suatu hal yang merugikan bagi manusia, sampah bisa berubah menjadi sesuatu yang bermanfaat jika manusia mengetahui teknik pengolahan yang tepat. Akan tetapi, selama ini masih banyak masyarakat yang menggunakan teknik tradisional dalam mengolah sampah dan kurang ramah dengan lingkungan. Langkah yang paling sederhana adalah dengan metode 3R yaitu Reduce, Reuse, dan Recycle. Jika metode ini sudah diterapkan setidaknya masyarakat telah membantu memilah dan mengolah sampah (Yunik'ati et al., 2019).

Berbeda dengan kasus diatas, cara yang digunakan masyarakat pedesaan masih bisa dikatakan sebagai bentuk pengolahan yang sangat tidak ramah lingkungan. Sampah biasanya dibuang di dalam suatu wadah tanpa adanya proses pemilahan. Selain itu, warga desa umumnya penanganan sampahnya dilakukan dengan cara-cara yang kurang dengan wawasan lingkungan, misalnya dengan membakar sampah, menimbun sampah di dalam tanah tanpa memilahnya, serta membuang sampah di sekitar aliran sungai. Kebiasaan tersebut telah berlangsung sejak zaman dahulu sampai dengan sekarang.

Desa Gunungsari merupakan salah satu desa yang terkenal sebagai penghasil bunga hias dan sayuran segar di Kota Batu. Mayoritas masyarakat disini berprofesi sebagai petani. Jadi, masih sangat banyak dijumpai rumah dengan taman-taman yang ditanami berbagai macam bunga hias seperti, mawar, krisan, peacock, dan masih banyak lainnya. Hasil panen bunga biasanya akan dikirimkan ke luar kota dan sebagiannya akan dijual di daerah Kota Batu.

Setiap musim panen tiba, bunga yang dihasilkan bisa mencapai ribuan bunga, maka tidak heran juga jika sampah yang dihasilkan dari sisa panen bunga cukup banyak. Sampah tersebut bisa berupa sisa potongan tangkai bunga atau bisa juga berupa bunga-bunga yang rusak. Selain itu, limbah rumah tangga jjuga menjadi salah satu penyebab menumpuknya sampah di Tempat Pembuangan Akhir (TPA) Desa Gunungsari. Lebih dari 70\% sampah yang ada disana merupakan sampah rumah tangga. Limbah rumah tangga yang termasuk dalam sampah organik dan sisa-sisa bunga bisa dimanfaatkan sebagai pupuk organik atau bisa juga dijadikan sebagai eco-Enzyme.

Eco-enzyme adalah ekstrak cairan yang dihasilkan dari fermentasi sisa sayuran dan buah-buahan dengan substrat gula merah atau molase. Prinsip proses pembuatan ecoenzyme sendiri sebenarnya mirip proses pembuatan kompos, namun ditambahkan air sebagai media pertumbuhan sehingga produk akhir yang diperoleh berupa cairan yang lebih disukai karena lebih mudah digunakan dan mempunyai banyak manfaat (Luthfiyyah et al., 2010). Keistimewaan eco-enzyme dibnadingkan dengan pembuatan kompos adalah tidak memerlukan lahan yang luas untuk proses fermentasi seperti pada proses pembuatan kompos, bahkan produk ini tidak memerlukan bak komposter dengan spesifikasi tertentu. Wadah yang diperlukan hanya wadah dari plastik dan mempunyai tutup yang masih rapat.

Sistem pengolahan sampah ini pertama kali ditemukan pada tahun 2003, seorang doktor dari Thailand menerima penghargaan dari FAO (lembaga PBB yang mengurus soal pangan) Regional Thailand untuk penemuannya yang bernama eco-enzyme. Penemuan ini merupakan suatu upaya yang dilakukan Dr. Rosukon Poompanvong bagi lingkungan dengan membantu para petani setempat untuk memperoleh hasil panen yang lebih baik sekaligus ramah lingkungan (Megah, dkk: 2018). Kemudian sistem pengolahan ini diperkenalkan secara luas oleh Dr. Joean Oon. Dia adalah peneliti dari Penang, Malaysia yang bekerja dibawah naungan Naturophaty (Sasetyaningtyas, 2018).

Pada tanggal 14 Februari 2021 mahasiswa dari kelompok 22 KSM (Kandidat Sarjana Mengabdi) Tematik Edisi Covid-19 (New Normal) Universitas Islam Malang, melaksanakan 
kegiatan pendampingan pemberdayaan masyarakat untuk membentuk masyarakat yang kreatif, inovatif, serta terampil. Kegiatan yang dilakukan adalah mendampingi bagaimana cara untuk mengolah limbah rumah tangga dengan membuat eco-enzyme. Eco-enzyme merupakan cairan alami serbaguna yang dibuat dari hasil fermentasi buah dan sayur yang dicampur dengan gula merah atau molase. Proses pembuatannya membutuhkan waktu kurang lebih 3 bulan untuk bisa dipanen hasilnya. Dalam hal ini, mahasiswa KSM Universitas Islam Malang berkolaborasi dengan PKK RW 04 Dusun Kandangan Desa Gunungsari.

Berdasarkan pemaparan diatas, permasalahannya yang terjadi adalah banyaknya sampah organik yang belum bisa dimanfaatkan dengan baik oleh masyarakat. Oleh karena itu, muncul gagasan untuk bisa memanfaatkan sampah tersebut untuk dijadikan sebagai ecoenzyme yang mempunyai banyak manfaat bagi masyarakat dan juga sebagai alternatif di masa pandemi Covid-19.

\section{METODE}

Pengabdian masyarakat ini dilakukan oleh mahasiswa Kandidat Sarjana Mengabdi (KSM) Tematik Berbasis Keilmuan dan Domisili, Universitas Islam Malang, Kelompok 22 Tahun Akademik 2020/2021, berkolaborasi dengan Dosen Pembimbing Lapangan dan masyarakat RW 04 Dusun Kandangan, Desa Gunungsari, Kecamatan Bumiaji, Kota Batu.

Metode yang digunakan dalam kegiatan ini adalah metode partisipatif, metode ini merupakan metode pendampingan denga tujuan untuk memberdayakan masyarakat atau kelompok mitra dalam meyelesaikan dan mencari solusi permasalahannya. Adapun menurut World Bank (1995) dalam Asnudin (2010), menyatakan bahwa metode partisipatif merupakan suatu proses dimana para pemilik kepentingan (stakeholders) mempengaruhi dan berbagi pengawasan atas inisiatif dan keputusan pembangunan serta sumber daya yang berdampak pada mereka. Jadi, metode partisipatif adalah metode yang mendorong keikutsertaan setiap individu didalam suatu proses kelompok tanpa memnadang usia, jenis kelamin, kelas sosial dan latar belakang pendidikan dari masing-masing pribadi yang tumbuh dari kesadaran dan tanggung jawabnya.

Pihak yang terkait dalam kegiatan ini adalah masyarakat Dusun Kandangan, Desa Gunungsari, Kecamatan Bumiaji, Kota Batu, lebih khususnya ibu-ibu PKK di wilayah RW 04 Dusun Kandangan. Bentuk kegiatan yang dilakukan diantaranya adalah melakukan sosialisasi tentang eco-enzyme yang langsung disampaikan oleh Ketua PKK dengan dibantu mahasiswa KSM, melakukan penyuluhan, menyiapkanalt dan bahan serta langsung melakukan praktik.

Tabel 1. Roadmap Program Pengabdian

\begin{tabular}{|c|c|c|c|c|c|}
\hline No. & $\begin{array}{c}\text { Metode } \\
\text { Pengabdian }\end{array}$ & Kegiatan & Tujuan & Output & $\begin{array}{c}\text { Waktu } \\
\text { Pelaksanaan }\end{array}$ \\
\hline 1. & $\begin{array}{l}\text { Sosialisasi cara } \\
\text { pembuatan dan } \\
\text { manfaat eco- } \\
\text { enzyme }\end{array}$ & PKK RW 04 & $\begin{array}{l}\text { - Memberikan } \\
\text { arahan terkait } \\
\text { pembuatan eco- } \\
\text { enzyme } \\
\text { - Memaparkan } \\
\text { manfaat dari eco- } \\
\text { enzyme }\end{array}$ & $\begin{array}{l}\text { Menyiapkan alat } \\
\text { dan bahan yang } \\
\text { dibutuhkan } \\
\text { untuk } \\
\text { pembuatan eco- } \\
\text { enzyme }\end{array}$ & $\begin{array}{l}\text { Minggu, } \\
14 \text { Februari } \\
2021\end{array}$ \\
\hline 2. & $\begin{array}{l}\text { Pendampingan } \\
\text { pembuatan eco- } \\
\text { enzyme }\end{array}$ & PKK RW 04 & $\begin{array}{l}\text { Pembuatan eco- } \\
\text { enzyme }\end{array}$ & $\begin{array}{l}\text { Campuran } \\
\text { molase, } \\
\text { potongan } \\
\text { buah/sayur, dan } \\
\text { air yang sudah } \\
\text { siap di } \\
\text { fermentasi }\end{array}$ & $\begin{array}{l}21 \text { Februari } \\
2021\end{array}$ \\
\hline
\end{tabular}




\section{HASIL DAN PEMBAHASAN}

Berdasarkan keputusan Menperindag RI No. 231/MPP/Kep/7/1997 Pasal I tentang prosedur impor limbah, menyatakan bahwa Limbah adalah bahan/barang sisa atau bekas dari suatu kegiatan atau proses produksi yang fungsinya sudah berubah dari aslinya, kecuali yang dapat dimakan oleh manusia dan hewan (Megah et al., 2018).

Limbah memang masih menjadi permasalahan utama dalam kehidupan masyarakat. Banyak cara yang telah dilakukan oleh masyarakat untuk mengolah limbah rumah tangga, akan tetapi masih sedikit yang bisa sukses menjalankannya. Dengan adanya sistem pengolahan limbah rumah tangga untuk dijadikan eco-enzyme diharapkan mampu memberikan solusi bagi masyarakat dan mampu memberikan manfaat dan dampak positif bagi lingkungan.

Berdasarkan asalnya, limbah dibagi ke dalam 3 kelompok, yaitu limbah rumah tangga, limbah pertanian, dan limbah industri. Oleh karena itu untuk memanfaatkan limbah rumah tangga sebagai benda yang bermanfaat dan mempunyai nilai guna. Sosialisasi kali ini tidak hanya menambah wawasan tentang pelestarian lingkungan, tetapi juga mengingatkan masyarakat bahwa pelestarian lingkungan bisa dimulai dari hal-hal yang sederhana. Maka dari itu kami menghadirkan system pengelolaan sampah dengan memanfaatkan sisa sayur dan buah-buahan dengan istilah eco-enzyme.

Kegiatan sosialisasi ini dilaksanakan pada hari Minggu, 14 Februari 2021 pada acara PKK rutin warga RW 04 Dusun Kandangan, Desa Gunungsari. Sasaran utama dari sosialisasi ini adalah ibu-ibu warga RW 04 yang juga bertindak sebagai relawan dalam pembuatan cairan eco-enzyme. Adapun tujuan utama sosialisasi ini adalah untuk memberikan wawasan dan arahan terkait bagaimana cara membuat cairan eco-enzyme, bahan-bahan yang harus dipersiapkan, serta manfaat dan tujuan pembuatan eco-enzyme.

Adapun kendala yang kami alami dalam pelaksanaan sosialisasi tentang eco-enzyme adalah masih kurangnya pengetahuan kami tentang proses pembuatan dan bagaimana cara mengatasi permasalahan yang muncul selama proses kegiatan.

Pendampingan kegiatan pembuatan eco-enzyme kami lakukan bekerja sama dengan $\mathrm{Bu}$ Ikrima selaku Ketua PKK RW 04 Dusun Kandangan. Sebenarnya beliau lah yang mempunyai ide tentang pengelolaan sampah tersebut, tetapi beliau juga mempunyai keterbatasan wawasan dan waktu sehingga kami dari KSM-Tematik UNISMA diajak untuk berkeja sama dalam menyelenggarakan kegiatan tersebut.

Sebelum melakukan kegiatan pembuatan cairan eco-enzyme, para relawan menyiapkan alat dan bahan yang dibutuhkan yaitu:

1. Gula merah atau molase

2. Sisa buah atau sayur, minimal 5 jenis buah atau sayur

3. Air

4. Wadah plastik kedap udara (drum bekas, botol bekas, dll).

Setelah menyiapkan alat dan bahan yang dibutuhkan, maka proses selanjutnya adalah mulai memotong buah atau sayur sesuai dengan ketentuan. Kemudian, kita bisa mencampurkan seluruh komponen tadi dalam wadah kedap udara (Rochyani et al., 2020). Tata cara pembuatan eco-enzyme adalah sebagai berikut:

1. Tuangkan air bersih ke dalam ember. Rasio air terhadap bahan bahan yang lain adalah 10. Sedangkan rasio sisa buah atau sayur adalah 3 , dan rasio untuk molase adalah 1 . Sehingga perbandingannya menjadi Air: buah/sayur: molase $=10: 3: 1$

2. Perlu diperhatikan bahwa akumulasi semua bahan yang akan dimasukkan ke dalam ember agar tidak memenuhi volume ember seutuhnya. Dibutuhkan ruang untuk gas hasil fermentasi.

3. Masukkan molase dan kemudian diaduk hingga terlarut dengan air - homogen. Molase berfungsi sebagai sumber gula bagi bakteri untuk melakukan fermentasi. 
4. Masukkan buah dan sayur ke dalam ember masing-masing. Buah dan sayur yang dimasukkan hendaknya dipotong kecil, ditimbang sesuai ukuran-ratio yang telah ditentukan dan diremas sehingga berukuran kecil. Ini bertujuan agar proses fermentasi dapat berjalan dengan baik.

5. Setelah semua bahan tercampur dengan baik, tutup ember agar udara luar tidak masuk. Hal ini dapat menggangu proses fermentasi (agar lebih kedap dapat juga gunakan plastic yang diikat dengan karet atau tali rafia) lalu ditutup.

6. Enzim yang telah dibuat disimpan di tempat yang tidak terjangkau oleh cahaya matahari, sehingga sistem benar-benar tertutup.

7. Fermentasi sempurna memakan waktu hingga 3 bulan.

Kendala yang dialami pada proses pendampingan ini adalah menentukan ratio atau timbangan yang sesuai dengan wadah fermentasi. Jika kita mengisi terlalu penuh maka gas hasil fermentasi bisa meledak karena tidak punya cukup ruang. Jadi, ratio atau timbangan bahan-bahan komponen harus diperhatikan dengan benar.

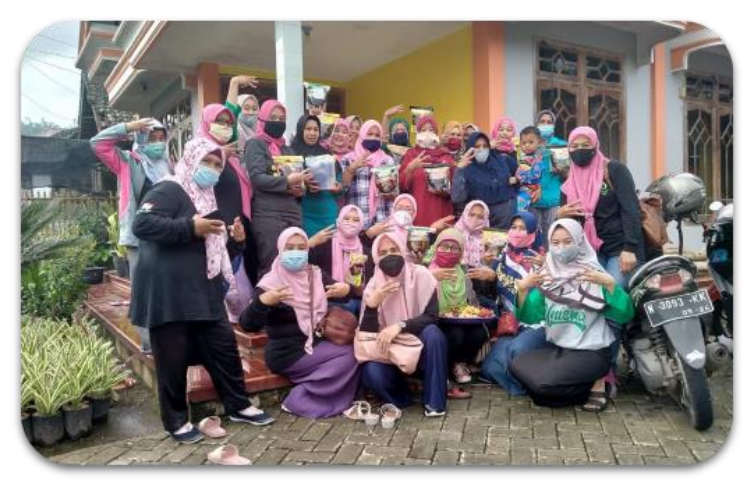

Gambar 1. Sosialisasi bersama PKK RW 04

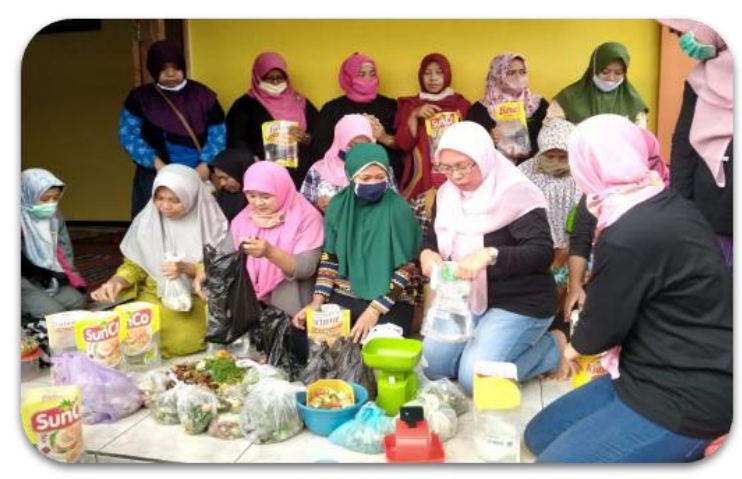

Gambar 2. Pemotongan bahan-bahan

\section{KESIMPULAN}

Kegiatan pengelolaan sampah organik menjadi bahan berguna bagi warga baik untuk kesehatan dan kebrsihan dilaksanakan berdasarkan program kerja KSM-TEMATIK Kelompok 22 di Dusun Kandangan Desa Gunungsari, hingga hasil kerjanya, maka kami menyimpulkan bahwa dengan kehadiran mahasiswa KSM dari Universitas Islam Malang terasa cukup membantu masyarakat RW 04 Dusun Kandangan Desa Gunungsari. Dengan memanfaatkan limbah rumah tangga yang bisa dimanfaatkan sebagai pengganti produkproduk kimia industri. Selain ramah lingkungan limbah rumah tangga bisa menjadikan nilai ekonomis bagi warga RW 04 Dusun Kandangan Desa Gunungsari karena selain lingkungan menjadi bersih juga tidak memerlukan biaya yang mahal untuk memperolehnya. Dengan memperkenalkan pengelolan limbah rumah tangga dengan eco-enzyme.

Eco-enzyme adalah cairan alami serbaguna yang dibuat dengan menggunakan bahan baku yang mudah di dapat dan murah. Proses fermentasinya yang selama 3 bulan, memang 
membutuhkan kesabaran. Namun, larutan yang dihasilkan memiliki khasiat yang sangat banyak. Manfaat yang ada dari eco-enzyme adalah bisa melancarkan saluran air yang tersumbat. Selain itu, bisa juga digunakan untuk menyiram tanaman akan memberi hasil buah, bunga, atau panen yang lebih dan dapat mengusir serangga-serangga pengganggu. Ampas sampah organik yang sudah difermentasi bisa digunakan sebagai bahan untuk kebersihan dan juga sebagai pupuk organik yang baik.

\section{DAFTAR RUJUKAN}

Asnudin, A. (2010). Pendekatan Partisipatif Dalam Pembangunan Proyek Infrastruktur Perdesaan di Indonesia. Jurnal SMARTek, 8(3), 182-190. http://jurnal.untad.ac.id/jurnal/index.php/SMARTEK/article/view/638

Clourisa, N., Susanto, A., Latief, M., \& Dyah, R. (2021). Pengenalan ecoprint guna meningkatkan keterampilan siswa dalam pemanfaatan bahan alam. Jurnal Inovasi Hasil Pengabdian Masyarakat (JIPEMAS), 4(36), 111-117. https://doi.org/10.33474/jipemas.v4i1.8974

Endah, S. M. D. (2015). Menuju Gaya Hidup Ramah Lingkungan : Sebuah Ilustrasi Tentang Sampah. In In: Kasih Akan Tanah Air Upaya Untuk Terus Menjadi (pp. 177-188). Kanisius.

Gischa, S. (2021). Usaha Masyarakat Untuk Menjaga dan Memelihara Sumber Daya Alam. Kompas.Com. https://www.kompas.com/skola/read/2021/01/15/155042869/usahamasyarakat-untuk-menjaga-dan-memelihara-sumber-daya-alam

Listiyani, N. (2017). Dampak pertambangan terhadap lingkungan hidup di kalimantan selatan dan implikasinya bagi hak-hak warga negara. Al'Adl, 9(1), 67-86. https://doi.org/10.31602/al-adl.v9i1.803

Luthfiyyah, A., Sylvia, Y. P., \& Farabi, A. (2010). Konsep Eco-Community Melalui Pengembangan Eco-Enzyme Sebagai Usaha Pengolahan Sampah Organik Secara Tuntas Pada Level Rumah Tangga. Bogor Agricultural University, Institut Pertanian Bogor. http://repository.ipb.ac.id/handle/123456789/27857

Megah, S. I. S., Dewi, D. S., \& Wilany, E. (2018). Pemanfaatan Limbah Rumah Tangga Digunakan Untuk Obat dan Kebersihan. Minda Baharu, 2(1), 50-58. https://doi.org/10.33373/jmb.v2i1.2275

Rochyani, N., Utpalasari, R. L., \& Dahliana, I. (2020). Analisis Hasil Konversi Eco Enzyme Menggunakan Nenas (Ananas comosus ) dan Pepaya (Carica papaya L.).Jurnal Redoks, 5(2), 135-140. https://doi.org/10.31851/redoks.v5i2.5060

Sasetyaningtyas, D. (2018). Manfaat dan Cara membuat Eco-Enzyme di rumah. Sustainition. https://sustaination.id/manfaat-dan-cara-membuat-eco-enzyme-di-rumah/

Yunik'ati, Imam, R. M., Hariyadi, F., \& Choirotin, I. (2019). Sadar Pilah Sampah Dengan Konsep 4R (Reduce, Reuse, Recycle, Replace) Di Desa Gedongarum, Kanor, Bojonegoro. Jurnal Inovasi Hasil Pengabdian Masyarakat (JIPEMAS), 2(2), 81-87. https://doi.org/10.33474/jipemas.v2i2.1122 